\title{
PROSES PERENCANAAN DAN PENGANGGARAN KEUANGAN DESA (Studi Di Desa-Desa Kecamatan Giri Mulya Kabupaten Bengkulu Utara)
}

\author{
Baihaqi ${ }^{1)}$ Ratih Pelita Sari ${ }^{2)}$, Dri Asmawanti $S^{3)}$ \\ Fakultas Ekonomi dan Bisnis, Universitas Bengkulu ${ }^{l, 2,3)}$

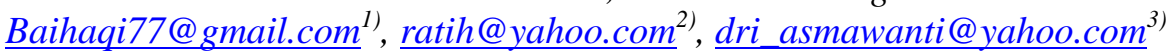

\begin{abstract}
This research is a descriptive qualitative research that aims to explain the condition of planning process and budgeting of village finances in the villages of Giri Mulya Sub-district, North Bengkulu Regency. The informants of this research are the village head, village secretary, head of the village consultative body, the empowerment of the village community of Giri Mulya sub-district, and representatives from the community. Data were collected through observation process, in-depth interview and documentation. The results of this study indicate that village planning and village financial budgeting have been outlined in accordance with the prevailing regulations. In terms of timeliness, in determining the work plan of the local government and budget of village income and expenditure, there was a delay due to the lack of human resources quality and the problem of regulatory delays from the district that reached the village head.
\end{abstract}

Keywords : planning and budgeting of village finances, Human Resources, regulatory

\section{PENDAHULUAN}

Indonesia adalah negara yang dibangun dari desa. Desa telah ada sebelum Negara Kesatuan Republik Indonesia ini terbentuk, bukti keberadaan desa telah dijelaskan dalam penjelasan Pasal 18 Undang-Undang Dasar Negara Republik Indonesia Tahun 1945(sebelum perubahan). Desa memiliki kedudukan dan peranan yang strategis sebagai unit organisasi pemerintah yang berhadapan langsung dengan masyarakat. Pemerintah desa diyakini mampu melihat prioritas masyarakat dibandingkan dengan pemerintah kabupaten yang secara nyata memiliki lingkup permasalahan yang lebih luas. Sehingga desa sebagai organisasi pemerintahan yang terendah harus diberi kewenangan untuk mengelola keuangannya sendiri, mulai dari tahapan perencanaan sampai tahap pengawasan dengan melibatkan stakeholders ditingkat desa, khususnya Badan Permusyawaratan Desa (BPD) dan organisasi masyarakat lainnya.

Salah satu bentuk kepedulian pemerintah dalam pembangunan desa adalah mengalokasikan dana yang bersumber dari APBN yaitu Dana Desa (DD). Dana Desa di alokasikan dari APBN berdasarkan Pasal 72 Ayat 1 Huruf b UU Nomor 6 Tahun 2014 tentang Desa. Dana Desa sangat penting untuk pembiayaan pengembangan wilayah tertinggal dalam suatu sistem wilayah pengembangan. Tujuan dialokasikannya Dana Desa adalah untuk mewujudkan pertumbuhan ekonomi yang inklusif dengan lebih memeratakan pendapatan. Pemerintah memposisikan desa sebagai fokus utama dalam hal pembangunan. Pemberian Dana Desa langsung dari APBN kepada desa merupakan salah satu bukti konkrit bahwa pemerintah pusat telah melaksanakan janjinya untuk melakukan pembangunan mulai dari pinggiran kota sampai dengan desa-desa tertinggal.

Pembangunan desa sebagai bagian dari pembangunan daerah mempunyai makna membangun masyarakat pedesaan dengan mengutamakan aspek kebutuhan masyarakat (Adisasmita, 2006:4). Pedoman pembangunan desa telah diatur dalam Peraturan Menteri Dalam Negeri Nomor 114 Tahun 2014. Keberhasilan suatu program pembangunan bukan 
hanya berdasarkan pada kemampuan pemerintah, tetapi juga berkaitan dengan partisipasi masyarakat dalam menjalankan program pembangunan. Pelaksanaan partisipasi masyarakat dalam pembangunan sangat diperlukan dalam setiap tahap pembangunan yang dimulai dari tahap perencanaan, tahap pelaksanaan, tahap pemanfaatan, serta tahap evaluasi (Huraerah, 2011:110).

Musyawarah Rencana Pembangunan Desa (musrenbang desa) merupakan upaya bertahap untuk mewujudkan otonomi desa dan gerakan penguatan otonomi desa, dan pemberdayaan desa. Musrenbang desa diharapkan dapat menghasilkan program kegiatan pembangunan desa yang benar-benar dibutuhkan masyarakat yang nantinya tertuang dalam APBDesa. Aparat desa dan seluruh komponen masyarakat di desa diharapkan untuk terlibat aktif menghimpun berbagai kebutuhan dan permasalahan yang ada di desa, kemudian dimusyawarahkan dan ditetapkan secara bersama, yang nantinya akan dijadikan prioritas pembangunan di desa masing-masing.

Permendagri Nomor 113 Tahun 2014 tentang Pengelolaan Keuangan Desa telah mengatur semua tahapan-tahapan pengelolaan keuangan desa mulai dari perencanaan, pelaksanaan, penatausahaan, pelaporan, dan pertanggungjawaban. Peneliti tertarik untuk meniliti perencanaan dalam keuangan desa, karena perencanaan merupakan tahapan pertama dan langkah awal dari pengelolaan keuangan desa. Perencanaan keuangan desa dilaksanakan dalam bentuk penyusunan Anggaran Pendapatan dan Belanja Desa (APBDesa) yang berasal dari Rencana Kerja Pemerintah Desa (RKP Desa) yang dihasilkan dari Musyawarah Rencana Pembangunan Desa (Musrenbang Desa) dengan berpatokan pada Rencana Pembangunan Jangka Menengah Desa (RPJM Desa).

Peneliti ingin menganalisa bagaimana desa-desa di Kecamatan Giri Mulya merencanakan dan menganggarkan keuangannya dan apakah pemerintah desa menjalankan perencanaan keuangan desa sesuai dengan peraturan yang berlaku serta sejauhmana pemerintah desa mentaati peraturan tersebut. Penelitian ini hanya berfokus pada perencanaan keuangan desa. Penelitian perencanaan dan penganggaran keuangan desa ini memilih objek penelitian di Kecamatan Giri Mulya, Kabupaten Bengkulu Utara.

Peraturan Menteri Negeri Dalam Negeri Nomor 113 Tahun 2014 tentang Pengelolaan Keuangan Desa, menyatakan bahwa penetapan APBDesa paling lambat 31 Desember tahun anggaran berjalan. Secara implisit, ketentuan ini menginginkan agar APBDesa ditetapkan lebih awal. Sehingga sebelum memasuki tahun anggaran baru, APBDesa sudah tersedia. Akan tetapi, di Kecamatan Giri Mulya sampai dengan bulan Januari masih melakukan musyawarah mengenai perencanaan pembangunan desa untuk tahun 2016. Jika dilihat dari kondisi tersebut, maka kecamatan Giri Mulya telah melakukan tindakan disipliner terhadap ketepatan waktu penetapan APBDesa. Keterlambatan penetepan APBDesa ini akan berdampak buruk, pelaksanaan realisasi pembangunan desa menjadi terhambat dan semua target awal akan meleset (tidak sesuai rencana). Penelitian ini ingin menjelaskan kondisi perencanaan dan penganggaran keuangan desa di Kecamatan Giri Mulya dan melihat kesesuaian perencanaan dan penganggaran keuangan desa di Kecamatan Giri Mulya dengan peraturan yang berlaku.

\section{KERANGKA TEORITIS DAN HIPOTESIS}

\section{Pengelolaan Keuangan Desa}

Permendagri Nomor 113 Tahun 2014 menjelaskan bahwa, pengelolaan keuangan desa adalah keseluruhan kegiatan yang meliputi perencanaan, pelaksanaan, penatausahaan, pelaporan, dan pertanggungjawaban keuangan desa. Dalam pelaksanaan pemerintah, pemerintah desa wajib mengelola keuangan desa secara transparan, akuntabel, partisipatif serta dilakukan dengan tertib dan disiplin anggaran. Pengelolaan keuangan Desa dikelola dalam masa 1 tahun anggaran, yaitu mulai tanggal 1 Januari sampai dengan tanggal 31 
Desember. Kekuasaan Pengelolaan Keuangan Desa dipegang oleh Kepala Desa. Namun demikian dalam pelaksanaannya, kekuasaan tersebut sebagian dikuasakan kepada perangkat desa sehingga pelaksanaan pengelolaan keuangan dilaksanakan secara bersama-sama oleh Kepala Desa dan Pelaksana Teknis Pengelolaan Keuangan Desa (PTPKD).

\section{Perencanaan dan Penganggaran Keuangan Desa}

Perencanaan dan penganggaran keuangan desa merupakan proses yang terintegrasi sehingga output dari perencanaan keuangan desa adalah penganggaran. Proses perencanaan arah dan kebijakan pembangunan desa tahunan dan rencana anggaran tahunan (APBDesa) pada hakikatnya merupakan perencanaan instrumen kebijakan publik sebagai upaya meningkatkan pelayanan kepada masyarakat. Oleh karena pentingnya anggaran tersebut maka perencanaan anggaran/penyusunan anggaran menjadi sesuatu yang penting dalam penyelenggaraan pemerintahan desa.

Perencanaan desa menurut Sujarweni bahwa pemerintah desa menyusun perencanaan pembangunan desa sesuai dengan kewenangannya dengan mengacu pada perencanaan pembangunan kabupaten dan kota. Rencana peembangunan desa disusun untuk menjamin keterkaitan dan konsistensi antara perencanaan, penganggran, pelaksanaan, dan pengawasan (Sujarweni, 2015: 18). Perencanaan pembangunan desa berdasarkan Permendagri Nomor 114 tahun 2014 pasal 4 disusun secara berjangka dan ditetapkan melalui peraturan desa. Dalam UU Nomor 6 Tahun 2014 peraturan desa ditetapkan oleh kepala desa setelah dibahas dan disepakati bersama Badan Permusyawaratan Desa (BPD). Perencanaan pembangunan desa disusun secara berjangka, meliputi RPJM Desa untuk jangka waktu 6 tahundanRencana pembangunan tahunan desa atau yang disebut RKP Desa merupakan penjabaran dari RPJM Desa untuk jangka waktu 1 tahun. RPJM Desa dan RKP Desa merupakan satu-satunya dokumen perencanaan di desa dan merupakan pedoman dalam penyusunan Anggaran Pendapatan dan Belanja Desa (APBDesa) yang diatur dalam Peraturan Pemerintah.

RPJM Desa berdasarkan Permendagri Nomor 114 Tahun 2014 pasal 6 ayat 1 memuat visi dan misi kepala desa, arah kebijakan pembangunan desa, serta rencana kegiatan yang meliputi bidang penyelenggaraan pemerintahan desa, pelaksanaan pembangunan desa, pembinaan kemasyarakatan desa, dan pemberdayaan masyarakat desa. Dalam pasal 7 dimana penyelenggaraan penyusunan RPJM Desa dengan mengikutsertakan unsur masyarakat desa dan mempertimbangkan kondisi objek desa, prioritas program, serta kegiatan kabupaten/kota. RPJM Desa ditetapkan dalam jangka waktu paling lama 3 (tiga) bulan terhitung sejak pelantikan kepala desa.

Sementara penjabaran dari RPJM Desa berupa rencana pembangunan tahunan desa atau yang disebut Rencana Kerja Pemerintah Desa (RKP Desa). BPD menyelenggarakan Musdes untuk penyusunan perencanaan pembangunan paling lambat bulan Junitahun berjalan. Hasil Musdes menjadi dasar untuk menyusun rancangan RKPDesa dan daftar usulan RKPDesa. Hasil kesepakatan dalam Musdes dituangkan dalam berita acara. Berita acara menjadi dasar kepala desa menyusun RKPDesa.

RKP Desa disusun oleh pemerintah desa sesuai dengan informasi dari pemerintah daerah kabupaten/kota berkaitan dengan pagu indikatif desa dan rencana kegiatan pemerintah, pemerintah daerah provinsi, dan pemerintah daerah kabupaten/kota. RKP Desa mulai disusun oleh pemerintah desa pada bulan Juli tahun berjalan dan ditetapkan dengan peraturan desa paling lambat akhir bulan September tahun berjalan. RKPDesa menjadi dasar dalam penyusunan APBDesa. Teknis penyusunan RPJMDesa dan RKPDesa agar tercipta keselarasan telah diatur tata caranya dalam Permendagri Nomor 114 Tahun 2014 tentang Pedoman Pembangunan Desa.

Setelah RKPDesa ditetapkan maka dilanjutkan proses penyusunan APBDesa. Rencana Kegiatan dan Rencana Anggaran Biaya yang telah ditetapkan dalam RKPDesa dijadikan 
pedoman dalam proses penganggarannya. Anggaran Pendapatan dan Belanja Desa (APBDesa) adalah instrumen penting dalam rangka mewujudkan tata kelola pemerintahan yang baik dalam pengelolaan pemerintah desa. Anggaran Pendapatan dan Belanja Desa (APBDesa) merupakan rencana anggaran keuangan tahunan pemerintah desa yang ditetapkan untuk menyelenggarakan program dan kegiatan yang menjadi kewenangan desa.

Perubahan APBDesa hanya dapat dilakukan 1 (satu) kali dalam 1 (satu) tahun anggaran. Tata cara pengajuan perubahan APBDesa secara umum sama dengan tata cara penetapan APBDesa. Dalam hal Bantuan Keuangan dari APBD Provinsi dan APBD Kabupaten/Kota serta hibah dan bantuan pihak ketiga yang tidak mengikat ke desa disalurkan setelah ditetapkannya Peraturan Desa tentang Perubahan APB Desa, maka perubahan tersebut diakomodir dan diatur dengan Peraturan Kepala Desa tentang perubahan APBDesa. Peraturan Kepala Desa tentang Perubahan APBDesa tersebut selanjutnya diinformasikan kepada BPD.

Permendagri Nomor 113 Tahun 2014 menjelaskan APBDesa terdiri dari pendapatan desa, belanja desa, dan pembiayaan desa. Pendapatan desa meliputi semua penerimaan uang melalui Rekening Kas Desa yang merupakan hak desa dalam 1 (satu) tahun anggaran yang tidak perlu dibayar kembali oleh desa. Belanja desa menurut Permendagri No. 113 Tahun 2014 meliputi semua pengeluaran dari rekening desa yang merupakan kewajiban desa dalam 1 (satu) tahun anggaran yang tidak akan diperoleh pembayarannya kembali oleh desa.Belanja desa dipergunakan dalam rangka mendanai penyelenggaraan kewenangan desa. Pembiayaan desa meliputi semua penerimaan yang perlu dibayar kembali dan/atau pengeluaran yang akan diterima kembali, baik pada tahun anggaran yang bersangkutan maupun pada tahun-tahun anggaran berikutnya.

\section{Jenis Penelitian}

\section{METODE PENELITIAN}

Untuk menggambarkan dan menyesuaikan perencanaan dan penganggaran keuangan desa berdasarkan peraturan yang berlaku dengan unsur-unsur pokok yang harus ditemukan sesuai dengan butir-butir rumusan masalah, tujuan dan manfaat penelitian, maka pendekatan yang digunakan dalam penelitian ini adalah penelitian kualitatif dengan menggunakan metode analisis deskriptif. Sebagaimana yang diungkapkan oleh Sugiyono (2015:1) metode kualitatif sering disebut metode penelitian naturalistik karena penelitiannya dilakukan pada kondisi yang alamiah (natural setting). Dalam rancangan penelitian ini, peneliti bermaksud mendalami situasi sosial seacara terbuka terkait proses perencanaan dan penganggaran keuangan desa, sehingga data dihasilkan melalui observasi (observation), wawancara, dan dokumentasi menggunakan kondisi yang alamiah (natural setting). Metode analisis yang digunakan peneliti menggunakan model interakif Miles and Huberman (1984), kegiatan analisis data terdiri dari tiga alur kegiatan yang terjadi secara bersamaan, yaitu reduksi data, penyajian data, dan penarikan kesimpulan/verifikasi. Untuk menguji kebasahan data yang didapat peneliti menggunakan uji kredibilitas dengan cara triangulasi dan member check.

\section{Metode Pengumpulan Data dan Analisis Data}

Pengumpulan data dan analisis data pada dasarnya dilakukan secara serentak (simultan). Dalam penelitian kualitatif, pengumpulan data dilakukan pada natural setting (kondisi yang alamiah), sumber data primer, dan teknik pengumpulan data lebih banyak pada observasi, wawancara, dan dokumentasi (Sugiyono, 2015: 63). Data diperoleh dari berbagai sumber, dengan menggunakan teknik pengumpulan data yang bermacam-macam (triangulasi), dan dilakukan secara terus-menerus sampai datanya jenuh. Analisis data dalam penelitian kualitatif dilakukan sejak sebelum memasuki lapangan, selama dilapangan, dan setelah selesai di lapangan. Analisis data tidak perlu menunggu semua data terkumpul. Data yang sudah terkumpul langsung dianalisis melalui proses reduksi data kemudian ditampilkan, 
setelah itu data yang sudah dianalisis dicek dan diperdalam lagi dilapangan kemudian dianalisis lagi dan ditampilkan, begitu seterusnya sampai ditemukan informasiyang baru tentang persoalan yang dianalisis dan terakhir disimpulkan.

Metode pengumpulan data merupakan proses yang menekankan pada cara peneliti untuk mengungkapkan proses mendapatkan data dari berbagai teknis, sumber, dan tindakan penelitian. Adapun metode pengumpulan data yang dipergunakan dalam penelitian ini adalah:

a) Observasi; Observasi merupakan teknik pengumpulan data yang dilakukan secara sistematis dan sengaja, yang dilakukan melalui pengamatan dan pencatatan gejala-gejala yang diselidiki. Dalam penelitian ini, observasi yang digunakan adalah observasi terang atau tersamar, dimana dalam pengumpulan data peneliti menyatakan terus terang kepada sumber data bahwa ia sedang melakukan penelitian. Sehingga informan penelitian mengetahui sejak awal sampai akhir aktivitas peneliti. Tetapi dalam suatu saat peneliti tidak terus terang dalam observasi untuk menghindari jika suatu saat ada data yang dicari merupakan data yang masih dirahasiakan.

b) Wawancara; Wawancara merupakan teknik pengumpulan data dalam metode survei yang menggunakan pertanyaan secara lisan kepada subjek penelitian. Pada saat pengajuan pertanyaan, peneliti dapat berbicara berhadapan langsung dengan responden, atau bila hal itu tidak mungkin dilakukan, juga bisa melalui alat komunikasi. Wawancara dilakukan dengan pihak yang benar - benar berkompeten agar memperoleh data yang lebih lengkap dan juga valid yang mungkin tidak terdapat pada dokumen. Wawancara dilakukan dengan pertanyaan terbuka dan juga menggunakan alat perekam untuk semakin memudahkan penulis dalam penulisan hasil wawancara karena akan diperoleh data yang lebih akurat dan dapat lebih mudah dalam memasukkannya ke laporan hasil penelitian perencanaan keuangan desa di Kecamatan Giri Mulya. Pada penelitian ini wawancara yang digunakan adalah wawancara semiterstruktur, dimana dalam pelaksanaan wawancara ini peneliti dapat bertanya lebih bebas, karena tujuan dari wawancara ini untuk menemukan permasalahan secara lebih terbuka, dimana pihak yang diwawancara diminta pendapat, dan ide-idenya. Informan dalam wawancara ini adalah Kepala Desa, Sekretaris Desa, Badan Permusyawaratan Desa, Perwakilan dari kelompok masyarakat, dan Camat atau yang mewakili.

c) Dokumentasi; Dokumentasi adalah teknik pengumpulan data berupa dokumen-dokumen atau arsip-arsip yang dapat memberikan informasi terkait data penelitian. Dokumen yang dimaksud adalah segala catatan baik berbentuk catatan dalam kertas (hardcopy) maupun elektronik (softcopy) seperti buku, artikel, media massa, undang-undang, notulen, blog, halaman web, foto, dan lainnya (Sanosa, 2012:61). Dokumentasi juga meruapakan catatan dari peristiwa masa lalu, dokumentasi dapat dijadikan sebagai alat kontrol utama untuk membuktikan kebenaran hasil wawancara (Sanjaya, 2013 : 74). Dokumentasi pada penelitian ini meliputi semua bentuk tulisan maupun gambar atau foto-foto terkait penelitian proses perencanaan dan keuangan desa.

\section{Metode Analisis Data}

Analisis data dalam penelitian kualitatif dilakukan sejak sebelum memasuki lapangan, selama di lapangan, dan setelah di lapangan. Namun dalam penelitian kualitatif, analisis data lebih difokuskan selama proses di lapangan bersamaan dengan pengumpulan data. Ada tiga tahapan menganalisis data, yaitu:

(1) Analisis Sebelum di Lapangan; Pada tahapan ini, peneliti melakukan pengamatan awal memasuki lokasi dengan membawa surat izin penelitian dan mengadakan pendekatan langsung terhadap objek penelitian baik secara formal maupun informal serta menjelaskan maksud dan kedatangan peneliti. Tahapan ini akan membangun komunikasi 
dengan informan di lokasi penelitian, sehingga pada saat pengumpulan data akan mendapatkan data sealamiah mungkin.

(2) Analisis selama di lapangan; Pada tahapan ini, peneliti menggunakan model interakif Miles and Huberman (1984) yang mengemukakan bahwa aktivitas dalam analisis data kualitatif dilakukan secara interaktif dan berlangsung secara terus menerus sampai tuntas, sehingga datanya sudah jenuh. Komponen dalam analisis data menggunakan model interakif Miles and Huberman (1984), antara lain:

(a) Pengumpulan Data (Data Collection); Pada tahapan ini penulis melaksanakan pengumpulan data yang dilaksanakan melalui observasi di lapangan, wawancara dengan narasumber, dan dokumentasi terkait kegiataan observasi dan wawancara yang telah dilakukan. Data yang terkumpul dipilah sesuai dengan sifat narasumber yang diteliti, yaitu kepala desa, sekretaris desa, BPD, masyarakat desa, dan camat atau yang mewakili. Data-data dari masing-masing sumber tersebut dipilah lagi berdasarkan kesamaan karakter yang bisa diungkap dan data yang dikumpulkan oleh penulis tersebut diubah dalam bentuk tulisan dengan pendapat yang diutarakan ke dalam catatan wawancara dan observasi/pengamatan.

(b) Reduksi Data (Data Reduction); Data yang diperoleh dari lapangan jumlahnya cukup banyak, maka dari itu perlu dicatat secara teliti dan rinci. Data yang telah direduksi akan memberikan gambaran yang lebih jelas, dan mempermudah peneliti untuk melakukan pengumpulan data selanjutnya, dan mencarinya bila diperlukan (Sugiyono, 2015:92). Reduksi data merupakan proses berfikir sensitif yang memerlukan kecerdasan dan keleluasaan dan kedalaman wawasan yang tinggi. Data yang diperoleh dari lokasi penelitian (data lapangan) dituangkan dalam uraian laporan yang lengkap dan terperinci. Laporan lapangan oleh peneliti direduksi, dirangkum dan dipilih hal-hal yang pokok, difokuskan pada hal-hal yang penting dan kemudian dicari polanya. Selama tahapan pengumpulan data berlangsung dilakukan tahap reduksi data, selanjutnya dengan cara membuat ringkasan, pengkodean, menelusuri pola, membuat gugus-gugus, dan menulis memorandum teoritis.

(c) Penyajian Data (Data Display); Setelah data direduksi, maka langkah selanjutnya adalah mendisplaykan data. Penyajian data bertujuan untuk melihat gambaran secara keseluruhan atau bagian-bagian tertentu dari penelitian. Data dapat disajikan dalam bentuk uraian singkat, bagan, hubungan antar kategori, flowchart, dan sejenisnya. Mendisplaykan data akan memudahkan untuk memahami apa yang terjadi, merencanakan kerja selanjutnya berdasarkan apa yang telah dipahami tersebut (Sugiyono, 2015:95). Pada penelitian ini penyajian data dilakukan dengan mengumpulkan informasi terkait proses perencanaan dan penganggaran keuangan desa yang terdapat dalam proses reduksi data sebelumnya dan disusun, sehingga memberi kemungkinan akan adanya penarikan kesimpulan. Penyajian data kemudian disusun melalui penelitian deskriptif kualitatif dalam bentuk naratif atau berbentuk penyajian lapangan.

(d) Penarikan kesimpulan atau verifikasi (Conclusion Drawing/Verifacation); Verifikasi data dalam penelitian kualitatif dilakukan secara terus-menerus selama penelitian berlangsung. Sejak awal memasuki lapangan dan selama proses pengumpulan data, peneliti berusaha menganalisis dan mencari makna dari dari data yang dikumpulkan dengan mencari pola, tema, hubungan persamaan, hal-hal yang sering timbul, dan yang dituangkan dalam kesimpulan. Kesimpuln awal yang dikemukakan masih bersifat sementara dan akan berubah bila tidak ditemukan bukti-bukti yang kuat yang mendukung pada tahap pengumpulan data berikutnya. Tetapi apabila kesimpulan yang dikemukakan pada tahapan awal didukung oleh bukti-bukti yang valid, maka 
kesimpulan yang dikemukakanmerupakan kesimpulan yang kredibel. Kesimpulan dapat berupa deskripsi atau gambaran suatu objek.

\section{Metode Pengabsahan Data}

Setiap penelitian memerlukan adanya standar unuk melihat kebenaran hasil penelitiannya. Pada penelitian kualitatif uji keabsahan data meliputi uji kredibilitas data, uji transferbility, uji depenability, dan uji confirmability. Dalam penelitian ini, peneliti menguji pengabsahan datanya dengan menggunakan uji kredibilitas. Adapun cara pengujian kredibilitas data dalam penelitian ini, yaitu:

1) Triangulasi; Triangulasi pada pengujian kredibilitas yaitu pengecekan data dari berbagai sumber dengan berbagai cara, dan berbagai waktu. Penelitian ini menggunakan triangulasi sumber untuk menguji kredibilitas data dilakukan dengan cara mengecek data yang telah diperoleh melalui beberapa sumber. Data yang telah diperoleh oleh peneliti kemudian dideskripsikan, dikategorisasikan, mana pandangan yang sama, yang berbeda, dan mana yang spesifik.

2) Member Check; Member check adalah proses pengecekan data yang diperoleh oleh peneliti kepada pemberi data dengan tujuan untuk mengetahui seberapa jauh data yang diperoleh sesuai dengan apa yang diberikan oleh pemberi data. Pelaksanaan membercheck dilakukan setelah satu periode pengumpulan data selesai, atau setelah mendapat suatu temuan (kesimpulan).Apabila data yang ditemukan oleh peneliti disepakati oleh pemberi data, maka data tersebut valid sehingga lebih kredibel/dipercaya. Tetapi apabila data yang ditemukan tidak disepakati oleh pemberi data, maka peneliti harus melakukan diskusi oleh pemberi data lagi. Setelah data disepakati bersama, maka para pemberi data diminta untuk menandatangani supaya lebih identik dan sebagai bukti bahwa peneliti telah melakukan member check.

\section{HASIL PENELITIAN}

\section{Deskripsi Wilayah Penelitian}

Kondisi fisik suatu wilayah memiliki peran penting karena berhubungan erat dengan aktivitas penduduknya. Pada kondisi sosial suatu wilayah tidak akan terlepas dari keadaan fisiknya. Hal ini dikarenakan kondisi fisik suatu wilayah memiliki peran untuk mengetahui faktor-faktor alami untuk mengetahui keadaan dan potensi yang sesuai untuk kawasan tersebut sehingga dapat diketahui aktivitas yang sesuai di kawasan tersebut. Batas-batas wilayah di Kecamatan Giri Mulya secara geografis adalah sebagai berikut:
1) Sebelah Utara
: Kabupaten Lebong dan Taman Nasional Kerinci Seblat
2) Sebelah Selatan
: Kecamatan Batik Nau
3) Sebelah Barat
: Kecamatan Ketahun
4) Sebelah Timur
: Kecamatan Padang Jaya

Kecamatan Giri Mulya adalah salah satu kecamatan di Kabupaten Bengkulu Utara Provinsi Bengkulu yang memiliki luas wilayah 14.386 Ha yang terbagi dalam 6 Desa. Kecamatan Giri Mulya memiliki rata-rata ketinggian berkisar 1000-1500 meter diatas permukaan laut. Kecamatan Giri Mulya pada tahun 2016 memiliki jumlah penduduk sebanyak 16.109 jiwa yang terdiri dari 8.208jiwa (51\%) laki-laki dan 7.901jiwa (49\%) perempuan. Jumlah penduduk sangat penting untuk dipertimbangan karena penduduk merupakan subjek pembangunan dan menjadi sasaran dari pembangunan. Penduduk memiliki peran dalam sumberdaya pembangunan di suatu desa. Kualitas sumberdaya penduduk dalam pembangunan dipengaruhi oleh berbagai faktor, yaitu dari jenis kelamin, kualitas sumber daya manusia, dan lain-lain. Kualitas sumber daya manusia dipengaruhi oleh tingkat pendidikan karena akan mempengaruhi pola pikir, perilaku, dan tindakan yang dimiliki. 
Semakin tinggi tingkat pendidikan penduduk, maka kualitas SDM juga akan semakin baik dan tingkat partisipasi masyarakat dalam pembangunan di suatu desa juga akan semakin baik. Semakin tinggi tingkat partisipasi masyarakat, maka akan semakin cepat dalam meningkatkan kualitas pembangunan di desa.

\section{Data Informan}

Data informan dalam penelitian ini berkaitan dengan perencanaan keuangan desa. Untuk tingkat Kecamatan, informan penelitian adalah Kasi PMD (Pemberdayaan Masyarakat Desa) Kecamatan Giri Mulya Kabupaten Bengkulu Utara yaitu Bapak Misno, A.md. Untuk tingkat desa, informan penelitian ini adalah kepala desa, sekretaris desa, ketua BPD yang menjabat pada tahun 2016, serta perwakilan masyarakat dari masyarakat yang hadir pada saat musrenbangdes.

\section{Perencanaan Keuangan Desa}

Menurut Peraturan Bupati Bengkulu Utara Nomor 12 Tahun 2016 tentang Perubahan Atas Peraturan Bupati Nomor 24 Tahun 2015 Tentang Pedoman Pengelolaan Keuangan Desa Dalam Kabupaten Bengkulu Utara, pemerintah desa menyusun perencanaan pembangunan desa sesuai dengan kewenangannya dengan mengacu pada perencanaan pembangunan pemerintah kabupaten Bengkulu Utara. Perencanaan pembangunan desa meliputi RPJM Desa dan RKP Desa yang disusun secara berjangka dan ditetapkan dengan Peraturan Desa. RKP Desa menjadi dasar untuk penyusunan APBDesa.

\section{Rencana Pembangunan Jangka Menengah Desa (RPJM Desa)}

Perencanaan desa dibagai menjadi perencanaan jangka menengah dan perencanaan jangka pendek. Perencanaan jangka menengah disebut dengan RPJM Desa (Rencana Pembangunan Jangka Menengah Desa) sementara perencanaan jangka pendek disebut RKP Desa (Rencana Kerja Pemerintah Desa). Peraturan Bupati Bengkulu Utara Nomor 12 tahun 2016 mengungkapkan bahwa dalam menyusun RPJMDesa, pemerintah desa wajib menyelenggarakan Musyawarah perencanaan pembangunan desa (Musrenbangdes) secara partisipatif. Musyawarah perencanaan pembangunan desa membahas dan menyepakati rancangan RPJM Desa. Hasil kesepakatan musyawarah perencanaan pembangunan Desa dituangkan dalam berita acara. Kepala desa mengarahkan Tim penyusun RPJM Desa melakukan perbaikan dokumen rancangan RPJM Desa berdasarkan hasil kesepakatan musyawarah perencanaan pembangunan Desa. Kepala Desa menyusun rancangan peraturan Desa tentang RPJM Desa.

Rancangan RPJM Desa dibahas dan disepakati bersama oleh kepala Desa dan Badan Permusyawaratan Desa (BPD) untuk ditetapkan menjadi Peraturan Desa tentang RPJM Desa.RPJM Desa ditetapkan dalam jangka waktu paling lama 3 (tiga) bulan terhitung sejak tanggal pelantikan kades terpilih. RPJM Desa disusun oleh tim penyusun RPJM Desa yang telah ditetapkan. Menurut Permendagri Nomor 114 tahun 2014 pasal 4 Perencanaan Pembangunan Desa Jangka Menengah atau RPJM Desa adalah perencanaan untuk jangka waktu 6 (enam) tahun dan ditetapkan dengan peraturan desa. Hal ini disampaikan oleh Bapak Mulyoto Kades Giri Mulya:

"Penyusunan RPJM Desa dilaksankan oleh tim penyusun RPJM Desa yang telah ditetapkan oleh kepala desa terpilih. Kepala desa selaku pembimbing dan sekretaris desa sebagai ketua yang dibantu oleh sembilan anggota penyusun. Tim penyusun RPJM Desa melaksanakan kegiatan sosialisasi, pengkajian desa, musyawarah dusun, penyusunan RPJM Desa, dan musrenbangdes."

Hal ini juga disampaikan oleh Bapak Dwi Priyono Kades Wonoharjo: 
"Ada tim khusus untuk penyusunan RPJM Desa yang terdiri paling banyak 11 orang, RPJM Desa disusun untuk program pembangunan enam tahun kedepan, disusun sesuai dengan visi dan misi kades terpilih, disusun berdasarkan hasil musrenbandes, dan disahkan paling lama tiga bulan setelah pelantikan kades terpilih."

Permendagri Nomor 114 Tahun 2014 menyatakan bahwa RPJM Desa disusun oleh kades terpilih (kades devinitif). Pada tahun anggaran 2016, semua kepala desa di Kecamatan Giri Mulya adalah Pejabat Sementara (Pjs), dikarenakan pada tahun 2016 masa jabatan kades lama sudah habis, sedangkan pilkades harus dilaksanakan serentak. Sehingga dalam penyusunan Rancangan RKP Desa mendasar pada RPJM Desa yang lama. RPJM Desa di desa-desa Kecamatan Giri Mulya yang tersedia hanya berlaku sampai tahun 2015 kecuali Desa Suka Mulya, sehingga para Pjs Kades menggunakan RPJM Desa lama dan dilakukanlah perubahan RPJM Desa untuk tahun 2016 dengan menambahkan prioritas di tahun 2016 berdasarkan atas perintah dari kabupaten yang diwakili oleh Kabid Pemdes BPMPD Kabupaten Bengkulu Utara pada saat sosialisasi di kecamatan. Hal ini disampaikan oleh Bapak Dwi Priyono Kades Wonoharjo:

"Pada tahun 2016, RPJM Desa tidak tersedia karena masa transisi dan semua kades di Kecamatan Giri Mulya hanyalah pejabat sementara, sedangkan pjs kades tidak boleh menyusun RPJM Desa, jadi untuk mengatasi proses pencairan dana desa yang memerlukan RPJM Desa maka kami para perangkat desa menambah RPJM Desa sebelumnya dengan tidak mengikuti prosedur yang ada karena kami hanya mengejar dana desa agar turun. Kami merubah hanya untuk satu tahun dengan menambahi apa yang menjadi prioritas pada tahun 2016. Kami sifatnya hanya menambah agar apa yang kami laksanakan tetap berpedoman dengan regulasi yang ada.Perubahan RPJM Desa ini emang dianjurkan oleh BPMPD kabupaten Bengkulu Utara dan diperintahkan pada saat sosialisasi di kecamatan yang diwakili oleh Kabid Pemdes BPMPD secara lisan."

\section{Musyawarah Rencana Pembangunan Desa (Musrenbangdes)}

Peraturan desa ditetapkan bersama melalui musyawarah perencanaan pembangunanan desa (musrenbangdes) yang dihadiri seluruh unsur lapisan masyarakat. Berdasarkan Permendagri Nomor 114 Tahun 2014 pasal 31 menyatakan Badan Permusywarat an Desa (BPD) menyelenggarakan musyawarah perencanaan pembangunan desa (musrenbangdes) paling lambat bulan Juni tahun anggaran berjalan. Berdasarkan Perbup Bengkulu Utara Nomor 12 Tahun 2016 disebutkan bahwa pada saat penyusunan rencana pembangunan desa melalui musyawarah desa yang dilakukan adalah pembentukan tim penyusun RKP Desa, lalu mencermati pagu indikatif desa hingga penyusunan rancangan RKP Desa yang selanjutnya dilakukan lagi pembahasan rancangan RKP Desa melalui musrenbang dan kemudian ditetapkanlah RKPDesa.

Perencanaan keuangan desa merupakan kegiatan dalam merumuskan pembangunan di desa. Perencanaan keuangan desa perlu untuk dilakukan agar penggunaan dana dapat lebih efektif, efisien, dan ekonomis serta tepat sasaran. Perencanaan keuangan desa dilakukan dengan berbagai tahap. Dalam merencanakan keuangan desa tahap yang pertama adalah dilakukan musyawarah perencanaan pembangunan desa, sebelum melakukan musrenbangdesa desa melakukan musyawarah dusun (musdus), yaitu kegiatan yang melibatkan kepala desa, BPD, dan perwakilan masyarakat dalam meninjau secara langsung dusun mana saja yang memiliki prioritas untuk dilakukan pembangunan.Hal itu sesuai dengan yang disampaikan oleh bapak M.Arbun, sebagai ketua BPD Desa Rena Jaya sebagai berikut:

"Sebelum kita melakukan musrenbangdes, terlebih dahulu dilakukan kegiatan yang bernama musyawarah dusun bersama kepala desa, kepala dusun, BPD, 
danmasyarakat untuk menentukan dusun mana saja yang harus di prioritaskan, dan pembangunan apa yang perlu dilakukan. Pada Tahun 2016 kami terjun langsung ke dusun-dusun."

Sama halnya dengan yang diungkapkan oleh Bapak Dwi Priyono, Kades Wonoharjo:

"Setiap tahun wajib melakukan musrenbangdes untuk menetapkan skala prioritas, tetapi sebelum melakukan musrenbangdes dilakukannya musyawarah dusun, hasil dari musyawarah dusun dibahas di musrenbangdes. Biasanya musrenbangdes di kecamatan Giri Mulya ini dilakukan setiap bulan januari. Sesuai dengan jadwal masing-masing. Jadi kami mengundang camat dan kasi PMD dari pihak kecamatan."

Dalam musyawarah dusun yang dibahas adalah apa yang telah disusun di RPJM Desa dan akan menjadi acuan dalam penyusunan RKP Desa tahun berjalan, seperti yang disampaikan oleh Bapak Mulyoto, kepala desa Giri Mulya:

"Hasil musyawarah dusun (musdus) itu sekitar bulan oktober terkhusus dalam bidang pembangunan. Hasil dari musdus adalah apa yang telah disusun dalam RPJM Desa untuk menetapkan pembangunan skala proritas yang akan dilaksanakan oleh pemerintah desa kedepan dalam melaksanakan pembangunan. Hasil kesepakatan pada saat musrenbang dijadikan sebagai acuan pemerintah desa dalam melaksanakan pembangunan yang akan dimasukkan dalam draf RKP Desa dalam melaksanakan pembangunan jangka tahunan di desa dan akan ditindaklanjuti oleh musrenbang kecamatan."

Dari keterangan informan tersebut, telah digambarkan secara jelas bahwa dalam menentukan pembangunan di desa menggunakan skala prioritas, sehingga dapat diketahui daerah mana saja yang pembangunannya perlu didahulukan. Secara umum desa-desa di kecamatan Giri Mulya telah melaksanakan musrenbang sesuai dengan peraturan bupati hingga menghasilkan skala prioritas pembangunan desa baik fisik maupun nonfisik yang disebut RKPDesa.

Kegiatan Musrenbangdes merupakan sebuah kegiatan mewujudkan keterlibatan dan respon masyarakat terhadap pembangunan desa, sehingga terbentuk sistem pemerintahan yang demokratis. Dalam musrenbangdes ada 4 (empat) bidang yang akan dibahas, yaitu bidang pemerintahan, bidang pembangunan, bidang pembinaan, dan bidang pemberdayaan. Hal ini sesuai dengan yang disampaikan oleh Bapak Mulyoto, kades Giri Mulya:

"Musrenbangdes wajib dilaksanakan oleh pemerintah desa guna untuk membahas usulan kegiatan yang akan dilaksanakan oleh pemerintah desa dalam melaksanakan kegiatan pembangunan yang telah disepakati dalam skala prioritas. Kegiatan itu meliputi bidang penyelenggaraan pemerintahan, bidang pembangunan, bidang pembinaan kemasyarakatan, dan bidang pemberdayaan. Dalam pelaksanaan musyawarah pembangunan desa dihadiri oleh ketua BPD dan anggota, tim penggerak $P K K$ desa dan wakil perempuan, seluruh perangkat desa, ketua $R T$ dan $R W$, tokoh masyarakat, tokoh agama dan karang taruna, serta masyarakat lainnya juga hadir pada saat musrenbang. Kami juga mengundang bapak Camat dan Kasi PMD, bapak kapolsek Giri Mulya, bapak koramil dan dari insatansi sekolah yang ada di desa. Guna untuk mengetahui dan menyepakati usulan-usulan yang akan dilaksanakan oleh pemerintah desa ke depan, pelaksanaan musrenbangdes semua anggaran biaya dibebankan oleh APBDesa." 
Senada dengan yang disampaikan Bapak oleh Pirwandi Kades Rena Jaya :

"Untuk tahun anggaran 2016 ada 4 item yang ada atau harus dilaksanakan, yaitu: bidang pemerintahan, pembangunan, pembinaan, dan pemberdayaan. Kemudian kita adakan musyawarah dan kita anggarkan untuk apa-apa saja dana yang ada, sekaligus membentuk tim pelaksana kegiatan."

Partisipasi masyarakat dalam pelaksanaan musrenbangdes sangatlah penting. Masyarakat harus berperan aktif dalam merencanakan pembangunan desa. Masyarakat yang akan menentukan skala prioritas pembangunan yang akan dilaksanakan. Apabila ditinjau dari tingkat partisipasi masyarakat dalam hal pengambilan keputusan pada saat musrenbang desa, dapat dikatakan bahwa tingkat partisipasi masyarakat di desa-desa yang ada di Kecamatan Giri Mulya tahun 2016 berada dalam kategori cukup baik.

\section{Rencana Kerja Pemerintah Desa (RKP Desa)}

Hasil dari RPJM Desa memuat Rencana Kerja Pembangunan Desa (RKP Desa) yang disusun tahunan dan dituangkan dalam rancangan APBDesa tahun berkenaan dan dicatat dalam pendapatan dan belanja desa. RKP Desa menjadi dasar dalam penyusunan Rancangan APBDesa (RAPBDesa). Kepala Desa menyusun RKPDesa dengan mengikutsertakan masyarakat desa. Tahapan RKPDesa sebagaimana yang dimaksud dilakukan dengan tahapan penyusunan perencanaan pembangunan desa, membentuk tim penyusun RKPDesa, pencermatan pagu indikatif desa, penyelarasan program/kegiatan yang masuk ke desa, pencermatan ulang dokumen RPJM Desa, penyusunan rancangan RKP Desa, Pembahasan rancangan RKP Desa melalui musyawarah perencanaan pembangunan desa (musrenbangdes), penetapan RKP Desa, perubahan RKP Desa, dan pengajuan daftar usulan rancangan RKP Desa, selanjutnya RKP Desa di tetapkan dengan peraturan desa.RKP Desa berdasarkan Permendagri Nomor 114tahun 2014 mulai disusun oleh pemerintah Desa pada bulan Juli tahun berjalan dan RKP Desa ditetapkan dengan peraturan Desa paling lambat akhir bulan September tahun berjalan.

Badan Permusyawaratan Desa menyelenggarakan musyawarah Desa dalam rangka penyusunan RKP Desa. Hasil musyawarah Desa menjadi pedoman bagi pemerintah Desa menyusun rancangan RKP Desa dan daftar usulan RKP Desa. Badan Permusyawaratan Desa menyelenggarakan musyawarah Desa paling lambat bulan Juni tahun berjalan. Musrenbang desa akan menghasilkan skala prioritas pembangunan di desa. Hasil kesepakatan musrenbang desa dituangkan dalam berita acara. Berita acara menjadi pedoman kepala Desa dalam menyusun RKP Desa dan ditetapkan dengan peraturan desa. Hal ini disampaikan dengan Bapak Suroso Kades Tanjung Anom :

"Berdasarkan hasil musyawarah desa, dari musrenbang itu diambil mana yang mendesak yang akan menjadi prioritas di tahun 2016, itulah yang menjadi rencana kerja pemerintah desa. Ada tim penyusun RKP Desa dan RKP Desa pada tahun anggaran 2016 ditetapkan bulan Juni."

Hal ini juga disampaikan oleh Bapak Tukino Kades Suka Makmur:

"Prosesnya yang pertama pembentukan tim penyusun RKP Desa. Kemudian kita adakan musyawarah desa yang akan dibahas skala prioritas yang dibahas disetiap dusun tadi. Setelah ada penetepan skala prioritas desa, kita bahas nanti dimusrenbangcam. Nanti RKP Desa ditetapkan dengan peraturan desa." 
RKP Desa di desa-desa Kecamatan Giri Mulyaterbagi menjadi 2 (dua) yaitu, RKP Desa berdasarkan hasil musrenbang dan RKP Desa berdasarkan hasil yang didanai dari dana transfer. Hal ini disampaikan oleh Bapak Misno Kasi PMD Kecamatan Giri Mulya :

"Hasil dari musrenbang akan menjadi Rencana Kerja Pemerintah Desa (RKP Desa). RKP Desa ada 2, yaitu RKP berdasarkan hasil musyawarah dan RKP Desa yang didanai dari dana transfer."

Sama halnya dengan yang disampaikan oleh Bapak Dwi Prioyono Kades Wonoharjo :

"RKP Desa ini ada dua, yaitu RKP Desa hasil dari musyawarah dan RKP Desa yang menetapkan penggunaan dana transfer. RKP Desa disusun berdasarkan RPJM Desa dan ditetapkan dengan peraturan desa."

Dari peraturan desa yang sudah ditetapkan di Kecamatan Giri Mulya rata-rata ditetapkan di bulan Mei dan Juni. Hal ini disebabkan karena pagu indikatif dari kabupaten lama turun. Permendagri Nomor 114 tahun 2014 menyebutkan bahwa kepala desa mendapatkan data dan informasi dari kabupaten/kota tentang pagu indikatif desa dan rencana program/kegiatan Pemerintah, pemerintah daerah provinsi, dan pemerintah daerah kabupaten/kota yang masuk ke Desaditerima kepala desa dari kabupaten/kota paling lambat bulan Juli setiap tahun berjalan. Sedangkan untuk tahun 2016 pagu indikatif desa diterima oleh kepala desa di Kecamatan Giri Mulya bulan Mei 2016. Keterlambatan lain juga disebabkan oleh kualitas SDM di desa yang kurang. Semakin baik kualitas SDM yang mengerjakan dan semakin cepat pagu indikatif sampai ke desa, maka semakin cepat pula proses penyusunan RKP Desa dan APBDesa, serta akan cepat pula proses pencairan dana dari pemerintah pusat kepada desa. Hal ini sesuai dengan yang disampaikan Kepala Desa Suka Mulya Bapak Asrul Junaidi sebagai berikut:

"Dalam penyusunan RKP Desa kami sedikit terlambat, karena perangkat baru, pengalaman belum punya, sumber daya manusia juga kurang, bahkan kualitas SDM juga kurang. Terus dalam pembuatan peraturan desa tidak boleh bertentangan dengan perda, jadi kami sedikit susah membuat perdes."

Hal ini juga disampaikan oleh Bapak Khomsin Sekdes Rena Jaya:

"Semua desa disini dalam menetapkan RKP Desa semuanya tidak ada yang tepat waktu, karena dalam menyusun RKP Desa kami menunggu adanya Perbub dulu, sedangkan pada tahun 2016 Perbupnya telat sampai ke desa-desa, otomatis kami juga telat menyusun RKP Desa."

Hal serupa juga disampaikan oleh Bapak Dwi Priyono Kades Wonoharjo :

"Karena kita tidak bisa menyusun kalau regulasi dari kabupaten belum ada. Kita harus melihat pagu anggaran dari kabupaten dulu. Sedangkan peraturan dari kabupaten aja baru ada sekitar bulan Mei. Keterlambatan ini juga disebabkan oleh pengetahuan SDM yang kurang, apalagi untuk menggunakan komputer, belum adanya peltihan khusus untuk perangkat desa."

\section{Anggaran Pendapatan dan Belanja Desa (APBDesa)}

Setelah RKP Desa ditetapkan maka dilanjutkan proses penyusunan APBDesa. Rencana biaya dan rencana anggaran biaya yang telah ditetapkan dalam RKP Desa dijadikan pedoman dalam proses penganggaran dalam APBDesa. Tahapan penyusunan APBDesa dalam Perbup Bengkulu Utara Nomor 12 Tahun 2016, sekretaris desa menyusun rancangan Peraturan Desa tentang APBDesa dan menyampaikannya kepada kepala desa. Dalam permendagri Nomor 113 tahun 2014 bab 5 pasal 20 menjelaskan bahwa secara teknis sekretaris desa menyusun 
Raperdes (Rancangan Peraturan Desa) tentang APBDesa berdasarkan RKP Desa tahun berkenaan. Kemudian Sekretaris Desa menyampaikan Raperdes tentang APBDesa kepada kepala desa untuk dibahas dan disepakati bersama dengan BPD paling lambat bulan Oktober tahun berjalan. APBDesa ditetapkan menjadi Peraturan Desa dan ditetapkan paling lambat 31 Desember tahun anggaran berjalan.

Sementara pada tahap perencanaan di desa-desa Kecamatan Giri Mulya ada tim khusus yang bertugas menyusun Raperdes tentang APBDesa, hal itu sesuai dengan yang disampaikan oleh Bapak Jumantri Sekdes Suka Mulya:

"Dalam menyusun rancangan menyusun rancangan peraturan desa tentang APBDesa, saya tidak menyusun sendiri, saya dibantu juga dengan tim penyusun lainnya, baru kami sampaikan ke kades jika sudah disusun, kemudian baru kades membahas rancangan tersebut dengan BPD untuk disepakati."

Hal itu sesuai dengan yang disampaikan Bapak Tukino Kades Suka Makmur:

"Ada tim perencanaanya sendiri, ada ketua, sekretaris, dan bendahara. Apalagi disini banyak pjs Kades yang merangkap jadi sekdes juga termasuk saya, sehingga diperlukannya tim untuk menyusun Raperdes tentang APBDesa itu, kemudian baru dibahas dan disepakati bersama dengan BPD"

Terkait fungsi BPD (Badan Permusyawaratan Desa) dalam tahap perencanaan semakin kuat dengan disahkannya undang-undang desa nomor 6 tahun 2014, salah satu fungsi BPD adalah membahas dan menyepakati Raperdes bersama kepala desa. Berdasarkan fungsi tersebut, BPD memiliki hak untuk menyetujui atau menolak Raperdes tentang APBDesa yang diajukan kepala desa. Peran BPD di desa-desa Kecamatan Giri Mulya fungsi BPD sudah cukup baik. Hal tersebut diungkapkan Bapak Karno Ketua BPD Wonoharjo :

"Dalam hal menyepakati kami sampai menggunakan hak tolak, tapi tahun kemaren membahas secara garis besar saja, tahun kemaren juga tidak ada yang harus kami tolak, karena sudah diadakannya musrenbangdes itu, kami BPD juga ikut dalam musrenbang itu. Jadi kami BPD tidak membahas terlalu jauh lagi, langsung menyepakati rancangan APBDesa tersebut."

Rancangan APBDesa yang telah disetujui dan disepakati oleh Kepala Desa dan ketua Badan Permusyawaratan Desa disampaikan kepada kepala BPMPD atas nama Bupati melalui camat untuk dievaluasi. Apabila dalam tahap evaluasi ditemukan adanya kekurangan, maka pihak kecamatan akan mengembalikan APBDesa kepada desa untuk segera dilengkapi dan proses pencairan dapat segera dilaksanakan. Hal itu sesuai dengan keterangan Bapak Jumantri Hadiwinata, sebagai sekretaris desa Suka Mulya sebagai berikut:

"Rancangan Peraturan desa tentangAPBDesa yang sudah kami susun, kami sampaikan ke BPMPD kami minta surat pengantar saja dari camat, terus kepala BPMPD yang mengevaluasi Rancangan Peraturan desa tentang APBDesa, Nah kalau dalam evaluasi tersebut ditemukan adanya kekurangan, maka dari BPMPD akan dikembalikan ke desa."

Sama halnya dengan yang disampaikan Bapak Mulyoto Kades Giri Mulya:

"Rancangan peraturan desa tentang APBDesa kami sampaikan ke kepala BPMPD, kami ke camat hanya minta surat pengantar, kalau tahun 2016 kemaren jika ada perbaikan saya langsung perbaiki disana, saya bawa laptop dan printer dari sini, tahun 2016 kita tidak menunggu beberapa hari langsung diperiksa langsung oleh BPMPD." 
Hal ini juga disampaikan oleh Bapak Dwi Priyono Kades Wonoharjo:

"Raperdes yang telah disusun disampaikan ke Bupati melalui BPMPD, setelah itu dievaluasi, kalau tahun 2016 kemarin tidak lama, paling lama 7 (tujuh) hari setelah kita kasih."

Dari informasi tersebut desa-desa di Kecamatan Giri Mulya dalam hal perencanaan keuangannya sudah mengikuti aturan yang ada, hanya saja dalam hal penetapan terjadi keterlambatan dikarenakan Peraturan Bupati yang lama disampaikan ke Kecamatan. Hal itu sesuai dengan yang disampaikan Bapak Misno, sebagai Kasi PMD Kecamatan Giri Mulya:

"Kalau untuk proses perencanaan, selama ini telah sesuai dengan prosedur yang berlaku, karena kalau belum sesuai, otomatis dana tidak akan bisa cair. Terbukti selama ini dana di desa-desa seluruh desa kecamatan Giri Mulya telah cair, walaupun tidak tepat waktu, tidak tepat waktu juga karena Perbup lama turun, kalau perbup saja belum ada bagaimana kami bisa merencanakan semuanya, kan semuanya sudah diatur di pagu anggaran."

\section{PENUTUP}

\section{Simpulan}

Berdasarkan hasil penelitian yang diperoleh maka dapat diambil kesimpulan sebagai berikut: (1) Perencanaan pembangunan desa disemua desa wilayah Kecamatan Giri Mulya secara garis besar telah disusun berdasarkan Permendagri Nomor 114 tahun 2014, (2) Penganggaran keuangan desa di desa-desa Kecamatan Giri Mulya berdasarkan Permendagri Nomor 114 tahun 2014 tentang Pedoman Pembangunan Desa dan Permendagri Nomor 113 tahun 2014 tentang Pengelolaan Keuangan Desa dalam sisi penetapan RKP Desa dan APBDesa terjadi masalah keterlambatan penyusunan peraturan desa. Hal ini disebabkan karena pagu indikatif dari pemerintah daerah kabupaten/kota untuk tahun 2016 diterima kepala desa di semua desa Kecamatan Giri Mulya dibulan Mei 2016 dan juga disebabkan oleh kualitas Sumber Daya Manusia (SDM) yang kurang, dan (3) Proses Penyusunan APBDesa secara garis besar telah disusun berdasarkan Peraturan Bupati Nomor 12 Tahun 2016 tentang Perubahan Atas Peraturan Bupati Nomor 24 tahun 2015 tentang Pedoman Pengelolaan Keuangan Desa Dalam Kabupaten Bengkulu Utara.

\section{Keterbatasan dan Saran Penelitian}

Penelitian ini hanya menyajikan perbandingan antara kesesuaian peraturan yang berlaku dengan aplikasi di lapangan, sehingga kelemahan pada penelitian ini adalah tidak membahas secara mendalam semua komponen atau tahapan pengelolaan keuangan desa dan tidak pula membahas nominal keuangan desa. Kurangnya kualitas dan pemahaman sumber daya manusia mengenai perencanaan keuangan desa di kecamatan giri mulya mengakibatkan sulitnya untuk berkomunikasi dan melakukan wawancara secara mendalam kepada para informan. Tidak adanya wawancara dengan pendamping desa, karena pendamping desa untuk tahun 2016 tidak bertempat tinggal di Kecamatan Giri Mulya. Selain itu, selama ini perintah penyusuna APBDesa yang dilakukan oleh pjs Kades hanya secara lisan yang diakibatkan oleh tidak adanya pedoman dan ketidaksiapan pemerintah daerah dalam mengatur kebijakan tentang pjs Kades boleh menyusun perencanaan dan penganggaran keuangan desa.

Berdasarkan simpulan dan keterbatasan yang dirumuskan oleh peneliti, maka dapat disarankan kepada penelitian selanjutnya untuk membahas mengenai komponen pengelolaan keuangan desa lainnya, seperti pelaksanaan, penatausahaan, pertanggungjawaban, serta pembinaan dan pengawasan. Selain itu, saran untuk objek peneliti adalah memperbaiki kekurangan kuantitas dan kualitas Sumber Daya Manusia (SDM) tim pelaksana melalui 
pendidikan dan pelatihan secara khusus, serta lebih tertib dan disiplin anggaran berdasarkan azas transparan, akuntabel dan partisipatif. Pemerintah daerah juga harus lebih siap dalam menangani masalah penyusunan APBDesa oleh pjs Kades dengan dibuatnya peraturan atau kebijakan tentang perencanaan dan penganggaran keuangan desa yang disusun oleh pjs Kades.

\section{DAFTAR PUSTAKA}

Adisasmita, Rahardjo. 2006. Pembangunan Perdesaan dan Perkotaan. Yogyakarta: Graha Ilmu

http://sekab.go.id/dana-desa-pemerintahan-jokowi-wujudkan-kedaulatan-desa/,18 Oktober 2016

Huraerah, Abu. 2011. Pengorganisasian dan Pengembangan Masyarakat. Bandung: Humaniora

Meleong, Lexy.J. 2007. Metedologi Penelitian Kualitatif. Bandung: Remaja Rosdakarya

Miles M.B Huberman MA, 1984. Qualitative Data Analysis;A sourccebook of New Methods; Sage Publicaitions, Beverly Hill, London

Nordiawan, Deddi. 2006. Akuntansi Sektor Publik. Jakarta: Salemba Empat.

Peraturan Bupati Bengkulu Utara Nomor 12 Tahun 2016 Tentang Perubahan Atas Peraturan Bupati Nomor 24 Tahun 2015 Tentang Pedoman Pengelolaan Keuangan Desa Dalam Kabupaten Bengkulu Utara

Peraturan Menteri Dalam Negeri Republik Indonesia Nomor 113 Tahun 2014 Tentang Pengelolaan Keuangan Desa

Peraturan Menteri Dalam Negeri Republik Indonesia Nomor 114 Tahun 2014 Tentang Pedoman Pembangunan Desa

Peraturan Pemerintah Nomor 8 Tahun 2016 Tentang Perubahan Kedua Atas Peraturan Pemerintah Nomor 60 Tahun 2014 Tentang Dana Desa Yang Bersumber Dari Anggaran Pendapatan dan Belanja Negara

Peraturan PemerintahNomor 47 Tahun 2015 Tentang Perubahan Atas Peraturan Pemerintah Nomor 43 Tahun 2014 Tentang Peraturan Pelaksanaan Undang-Undang No. 6 Tahun 2014 tentang Desa

Peraturan Pemerintah Desa, Pembangunan Daerah Tertinggal, dan Transmigrasi Nomor 21 Tahun 2015 Tentang Penetapan Prioritas Penggunaan Dana Desa Tahun 2016

Ramadhan, Riza. 2014. Analisis Perbandingan Pengelolaan Keuangan Desa Bangsri Dengan Pengelolaan Keuangan Desa Menurut Permendagri No. 37 Tahun 2007. Universitas Jember

Rosalinda, Okta. 2014. Pengelolaan Alokasi Dana Desa (ADD) Dalam Menunjang Pembangunan Pedesaan (studi kasus: Desa Segodorejo dan Desa Ploso Kerep, Kecamatan Sumobito, Kabupaten Jombang). Jurnal Ilmiah. Malang: Universitas Brawijaya Malang.

Sugiyono. 2015. Metode Penelitian Kualitatif dan R\&D. Bandung: Alfabeta CV 
Undang-Undang Nomor 23 Tahun 2014 Tentang Pemerintah Daerah

Undang-Undang Nomor 6 tahun 2014 Tentang Desa

Wahyuni, Indah. 2015.Analisis Pelaksanaan Keuangan Desa Rowogempol Menurut Permendagri Nomor 113 Tahun 2014 (Studi Kasus Pada Desa Rowogempol Kecamatan Lekok Kabupaten Pasuruan Periode 2015). Universitas Jember

Sanjaya, Wina. 2013. Penelitian Pendidikan Jenis, Metode, dan Prosedur. Jakarta: Prenada Media Group

Tamtama, Derro Madya. 2014.Akuntabilitas Pengelolaan ADD (Alokasi Dana Desa) di Kabupaten Madiun Tahun 2013 (Studi Kasus Pada Kecamatan Kare). Universitas Jember

Yuliansyah. Rusmianto. 2016. Akuntansi Desa. Jakarta: Salemba Empat 